\title{
Biodegradation of crude oil by individual bacterial strains and a mixed bacterial consortium
}

\author{
Santina Santisi ${ }^{1,2}$, Simone Cappello ${ }^{1}$, Maurizio Catalfamo ${ }^{1}$, Giuseppe Mancini ${ }^{3}$, \\ Mehdi Hassanshahian ${ }^{4}$, Lucrezia Genovese ${ }^{1}$, Laura Giuliano ${ }^{1}$, Michail M. Yakimov ${ }^{1}$ \\ ${ }^{1}$ Institute for Coastal Marine Environment, National Counsel of Research, Messina, Italy. \\ ${ }^{2}$ School in "Biology and Cellular Biotechnology", Faculty of Sciences, \\ University of Messina, Messina, Italy. \\ ${ }^{3}$ Department of Industrial Engineering, University of Catania, Catania, Italy. \\ ${ }^{4}$ Department of Biology, Faculty of Sciences, Shahid Bahonar University of Kerman, Kerman, Iran.
}

Submitted: December 2, 2013; Approved: June 6, 2014.

\begin{abstract}
Three bacterial isolates identified as Alcanivorax borkumensis SK2, Rhodococcus erythropolis HS4 and Pseudomonas stutzeri SDM, based on 16S rRNA gene sequences, were isolated from crude oil enrichments of natural seawater. Single strains and four bacterial consortia designed by mixing the single bacterial cultures respectively in the following ratios: (Alcanivorax: Pseudomonas, 1:1), (Alcanivorax: Rhodococcus, 1:1), (Pseudomonas: Rhodococcus, 1:1), and (Alcanivorax: Pseudomonas: Rhodococcus, 1:1:1), were analyzed in order to evaluate their oil degrading capability. All experiments were carried out in microcosms systems containing seawater (with and without addition of inorganic nutrients) and crude oil (unique carbon source). Measures of total and live bacterial abundance, Card-FISH and quali-, quantitative analysis of hydrocarbons (GC-FID) were carried out in order to elucidate the co-operative action of mixed microbial populations in the process of biodegradation of crude oil. All data obtained confirmed the fundamental role of bacteria belonging to Alcanivorax genus in the degradation of linear hydrocarbons in oil polluted environments.
\end{abstract}

Key words: Alcanivorax, Pseudomonas, Rhodococcus, bioremediation, bioaugmentation.

\section{Introduction}

Petroleum hydrocarbons are the most widespread contaminants within the marine environment. Pollution by hydrocarbons in marine environments may be the consequence of various natural (natural seepages) and/or anthropogenic activities (discharge during tanks and/or ships transportation and/or pipeline failures) as well as the chronic pollution (ships, harbours, oil terminals, freshwater run-off, rivers and sewage systems).

The "fate" of petroleum in the sea water largely depends on mechanical (wave, wind), physical (temperature, $\mathrm{UV}$ ) and chemical ( $\mathrm{pH}$, dissolved oxygen and nutrient concentration) factors which may differently influence its natural transformation (oil weathering) and bio-degradation (Nikolopoulou and Kalogeraki, 2010). At an early stage light fractions of oil are naturally removed; mostly by evaporation, thence by photo-oxidation and by geo-chemicals reactions. Heavy fractions are instead dispersed or dissolved and only a small portion may be removed by the process of biodegradation. Although chemical-physical phenomena play an important role in the process of oil detoxification, the ultimate and complete degradation is mainly accomplished by marine microflora, dominant bacteria in this role (Della Torre et al., 2012).

As reported in different studies, a wide variety of marine bacteria are known to degrade petroleum hydrocarbons, and those, distributed over several (sub)phyla ( $\alpha-, \beta-$, and $\gamma$-Proteobacteria; Bacteroidetes/Chlorobi group) have been described so far (Rooling et al., 2004; Cappello et al., 2007).

Send correspondence to S. Cappello. Institute for Coastal Marine Environment, CNR of Messina, Sp. San Raineri 86, 98121 Messina, Italy. E-mail: simone.cappello@iamc.cnr.it. 
In the natural environment, biodegradation of crude oil involves a succession of species within the consortia of the present microbes (Alkatib et al., 2011). Indeed, since a single species can metabolize only a limited range of hydrocarbon substrates, a consortium of many different bacterial species, with broad enzymatic capacities, is usually involved in oil degradation (Rooling et al., 2002). Although some bacteria, belonging to Pseudomonas (Das and Chandar, 2011) and Rhodococcus genera (Hassanshahian et al., 2010 and 2012) have shown able to degrade hydrocarbons (Teramoto et al., 2010), in marine environments the key micro-organisms in the bio-degradation process has been identified as bacteria related to Alcanivorax genus (Yakimov et al., 2007; Cappello and Yakimov 2010).

On the above mentioned basis, bioremediation techniques have been developed and improved for cleaning up oil-polluted marine environments as an alternative to chemical and physical techniques (Alkatib et al., 2011). Bioremediation can be described as the conversion of pollutants (hydrocarbons) by micro-organisms (bacteria) into energy, cell mass and biological waste products (Nikolopoulou and Kalogeraki, 2010). Nevertheless, the rates of uptake and mineralization of many organic compounds (hydrocarbons) by bacteria in polluted seawater is limited due to the poor availability of nitrogen and phosphorus (Yakimov et al., 1998; Kasai et al., 2002a, b; Cappello and Guglielmino, 2006; Cefalì et al., 2002). For that reason, in the application of biostimulation techniques the growth of oil-degrading bacteria can be strongly enhanced by fertil- ization with inorganic nutrients (Nikolopoulou and Kalogeraki, 2010).

In order to elucidate the cooperative action of mixed microbial populations in the biodegradation of crude oil, we have built up artificial consortia made up of two/three bacteria. By using these consortia, we have been able to investigate the capability of efficient biodegradation of crude oil could be accomplished by the mixed populations. All experiments have been carried out into microcosms systems containing seawater (with and without inorganic nutrients); oil has been used as the only carbon source.

The knowledge of the efficiency and the activities of bacteria in oil-polluted sites may be helpful for the bioremediation of oil spills, since human action, by using specific microbial consortia, can be planned in order to clean up oil pollution (Denaro et al., 2005).

\section{Material and Methods}

\section{Bacterial strains}

Three bacterial strains named isoSS-01, corresponding to Alcanivorax borkumensis strain SK2 ${ }^{\mathrm{T}}$ (Genbank accession number Y12579; =DSM $11573^{\mathrm{T}}$; 99\%), isoSS-02 (Rhodococcus erythropolis HS4; Genebank accession number AY168582; 99\%) and isoSS-03 (Pseudomonas stutzeri SDM; Genebank accession number DQ358054; 98\%) were used in all the experiments (Fig. 1). Strain isoSS-01 belong to a collection of hydrocarbon-degrading bacteria hold at IAMC-Messina, strains isoSS-2 and iso-

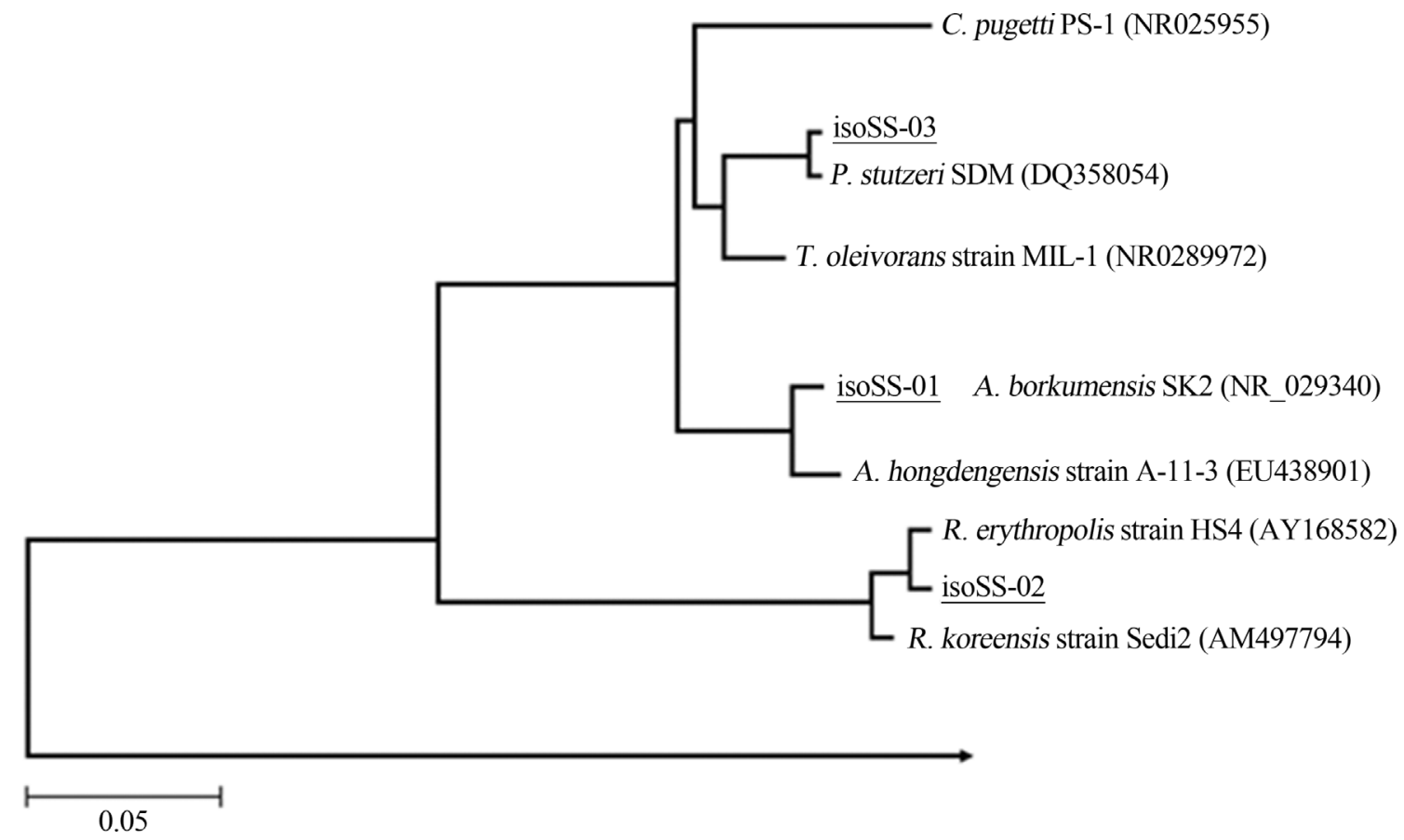

Figure 1 - Phylogenetic tree based on 16S rRNA gene sequences for bacterial strains (isolates isoSS-01, -02 and -03) used in this study. Percentages of 100 bootstrap resampling that supported the branching orders in each analysis are shown above or near the relevant nodes. The tree was rooted and outgrouped (black arrow) by using the 16S rRNA sequences of Methanococcus jannaschii (M59126). Evolutionary distance is indicated by vertical lines; each scale bar length corresponds to 0.05 fixed point mutations per sequence position. 
SS03 were isolated from natural seawater from crude oil enrichments in previously research. All strains used in this study were isolated from natural seawater from crude oil enrichments.

\section{Analysis of $16 \mathrm{~S}$ rRNA genes}

Total DNA extraction of bacterial strains was performed by the MasterPure Complete DNA\&RNA Purification Kit (Epicenter, Biotechnologies, Madison, WI) in accordance with manufacture's protocol. The 16S rDNA loci were amplified using 1 primer pair: the $27 \mathrm{~F}$ (5'-AGAGTTTGATCCTGGCTCAG-3', Lane, 1991) primer and the 1492R (5' TACGGYTACCTTGTTACGACT-3', Lane, 1991) universal primer. PCR (polymerase chain reaction) was carried out in $50 \mu \mathrm{L}$ of reaction mixture containing $1 \mathrm{x}$ reaction buffer, 1x solution Q (both from QIAGEN), $1 \mu \mathrm{M}$ of each primer, $200 \mu \mathrm{M}$ dNTP (Gibco), $1 \mu \mathrm{L}$ of template and $2.5 \mathrm{U}$ of Qiagen Taq polymerase. The PCR reaction was carried out in Mastercycler Gradient (Eppendorf); the PCR conditions were as follows: $95{ }^{\circ} \mathrm{C}$ for $5 \mathrm{~min}(1 \mathrm{cycle}) ; 94{ }^{\circ} \mathrm{C}$ for $1 \mathrm{~min}, 50^{\circ} \mathrm{C}$ for $1 \mathrm{~min}$ and $72^{\circ} \mathrm{C}$ for $2 \mathrm{~min}$ ( 35 cycles); with a final extension step at $72{ }^{\circ} \mathrm{C}$ for $10 \mathrm{~min}$. PCR products were sequenced using Macrogen Service (Macrocen, Korea). The analysis of the sequences (1400 bp of average length) was performed as previously described by Yakimov et al. (2005). The sequences similarity of individual inserts was analysed by the FASTA program Nucleotide Database Query available through the EMBL-European Bioinformatics Institute. The phylogenetic affiliation of the sequenced clones, was performed as described by Yakimov et al. (2006).

\section{Growth conditions}

Started cultures were prepared by inoculating one loop of microbial cells into $10 \mathrm{~mL}$ of ONR7a mineral medium based on the composition of seawater was used in this study (Dyksterhouse et al., 1995). Nitrogen was provided in the form of $\mathrm{NH}_{4} \mathrm{Cl}$, and was provided in the form of $\mathrm{Na}_{2} \mathrm{HPO}$, ONR7a contained (per liter of distilled or deionized water) $22.79 \mathrm{~g}$ of $\mathrm{NaCl}, 11.18 \mathrm{~g}$ of $\mathrm{MgCl}_{2} * 6 \mathrm{H}_{2} \mathrm{O}$, $3.98 \mathrm{~g}$ of $\mathrm{Na}_{2} \mathrm{SO}_{4}, 1.46 \mathrm{~g}$ of $\mathrm{CaCl}_{2},-2 \mathrm{H}_{2} \mathrm{O}, 1.3 \mathrm{~g}$ of TAPSO $\{3-[\mathrm{N}$-tris(hydroxymethyl)

methylamino]-2-hydroxypropanesulfonic acid\}, $0.72 \mathrm{~g}$ of $\mathrm{KCl}, 0.27 \mathrm{~g}$ of $\mathrm{NH}_{4} \mathrm{Cl}, 89 \mathrm{mg}$ of $\mathrm{Na}_{2} \mathrm{HPO}_{4} * 7 \mathrm{H}_{2} \mathrm{O}, 83 \mathrm{mg}$ of $\mathrm{NaBr}, 31 \mathrm{mg}$ of $\mathrm{NaHCO} 3,27 \mathrm{mg}$ of $\mathrm{H}_{3} \mathrm{BO}_{3}, 24 \mathrm{mg}$ of $\mathrm{SrCI}^{*} 6 \mathrm{H}_{2} \mathrm{O}, 2.6 \mathrm{mg}$ of $\mathrm{NaF}$, and $2.0 \mathrm{mg}$ of $\mathrm{FeCl}_{2} * 4 \mathrm{H}_{2} 0$. To prevent precipitation of ONR7a during autoclaving, three separate solutions were prepared and then mixed together after autoclaving when the solutions had cooled to at least $50{ }^{\circ} \mathrm{C}$; one solution contained $\mathrm{NaCI}, \mathrm{Na}_{2} \mathrm{SO}_{4}, \mathrm{KCl}, \mathrm{NaBr}$, $\mathrm{NaHCO}_{3}, \mathrm{H}_{2} \mathrm{BO}_{3}, \mathrm{NaF}, \mathrm{NH}_{4} \mathrm{Cl}, \mathrm{Na}_{2} \mathrm{HPO}_{4}$, and TAPSO (pH adjusted to 7.6 with $\mathrm{NaOH}$ ), the second solution contained $\mathrm{MgCl}_{2}, \mathrm{CaCl}_{2}$, and $\mathrm{SrCI}$, (divalent cation salts), and the third solution contained $\mathrm{FeCl}_{2} ; 0.1 \%(\mathrm{w} / \mathrm{v})$ sterile tetra- decane $\left(\mathrm{C}_{14} \mathrm{H}_{30}\right.$, Sigma-Aldrich, Milan, Italy) was used as only energy and carbon source. After growing in a rotary shaker (New Brunswick C24KC, Edison NJ, USA; $150 \mathrm{rpm}$ ) at $25^{\circ} \mathrm{C}$ for two days, $500 \mu \mathrm{L}$ of the seed culture broth were transferred into a $250 \mathrm{~mL}$ Erlenmeyer flask containing $100 \mathrm{~mL}$ of ONR7a medium supplemented with 1\% $(\mathrm{w} / \mathrm{v})$ sterile tetradecane. The culture was incubated in a rotary shaker (New Brunswick C24KC, Edison NJ, USA; $150 \mathrm{xg}$ ) at $25^{\circ} \mathrm{C}$ for 5 days.

\section{Consortia}

At the beginning $\left(\mathrm{T}_{0}\right)$ of the experiments selected microorganisms (isoSS-01, A. borkumensis $\mathrm{SK} 2^{\mathrm{T}}$; iso-SS-02, R. erythropolis HS4 and iso-SS-03 Ps. stutzeri SDM) were added at a final density of $10^{5}$ cell $\mathrm{mL}^{-1}$, in experimental microcosms. Schematic representation of microbial consortia used in this study is indicated below (Fig. 2).

\section{Experimental set-up of microcosms systems}

The microcosms systems were performed in $250 \mathrm{~mL}$ sterilised Erlenmeyer flasks. Microcosms were incubated at $22 \pm 1{ }^{\circ} \mathrm{C}$ for 15 days with shaking $(100 \mathrm{~g})$. All experiments were carried out in triplicate.

Two different series of experimentations were carried out. In the first experiment (identified as "SW") bacterial cultures were carried out in natural seawater sterilized by

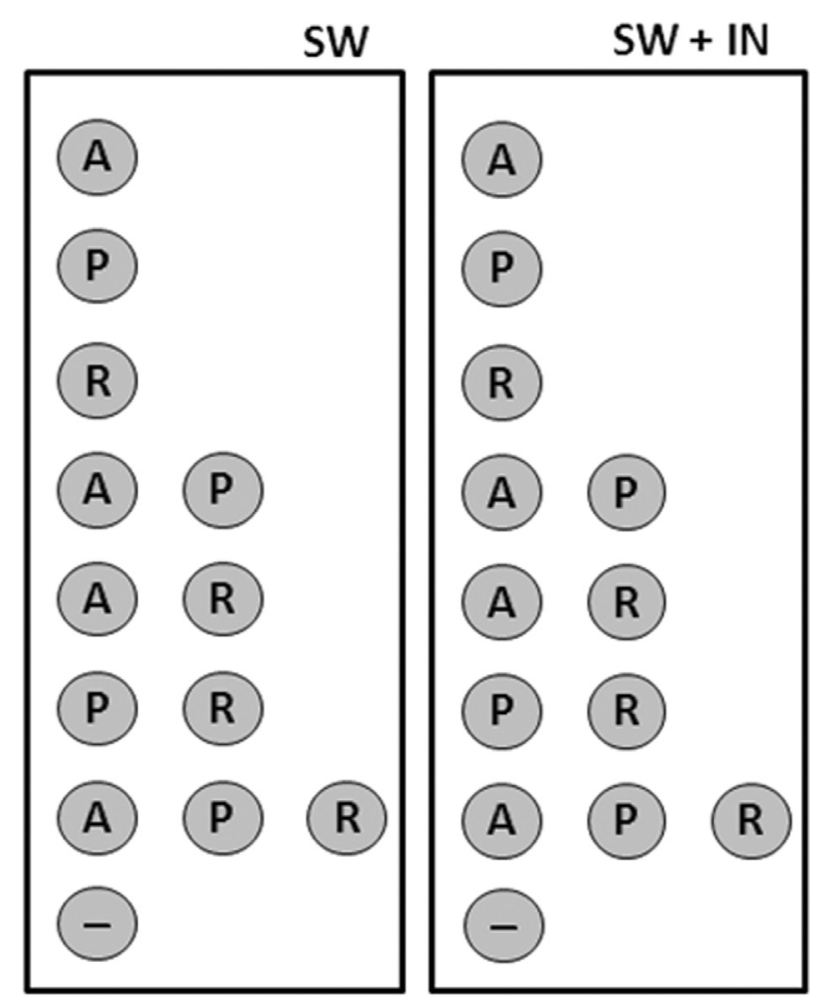

Figure 2 - Schematic representation of microbial consortia and experimental microcosms carried out in this study. A, isolate isoSS-01, (A. borkumensis SK2); P, isolate iso-SS-03 (Ps. stutzeri SDM); R, isolate iso-SS-02 (R. erythropolis HS4); -, negative abiotic control. 
filtration through a $0.2-\mu \mathrm{m}$ syringe filter (Sartorius); in the second experiment (identified "SW+IN") cultures were carried out in sterile natural seawater with addition of inorganic nutrients to reach higher concentrations than those obtained in natural water (final concentrations: $\mathrm{KH}_{2} \mathrm{PO}_{4} 0.077 \mathrm{~g} \mathrm{~L}^{-1}, \mathrm{NH}_{4} \mathrm{Cl} 0.2 \mathrm{~g} \mathrm{~L}^{-1}$ and $\left.\mathrm{NaNO}_{3} 0.1 \mathrm{~g} \mathrm{~L}^{-1}\right)$. Microcosms untreated (no bacteria inoculation) were used in each experiment series as negative (abiotic) control. Crude oil was added in all experimentation.

At the beginning $\left(\mathrm{T}_{0}\right)$ of the experiments, $1000 \mathrm{ppm}$ of sterile crude oil (Arabian Light Crude Oil; ENI Technology S.p.A.) were added into $\mathrm{SW}$ and $\mathrm{SW}+\mathrm{IN}$ microcosms. Crude oil was introduced, in microcosm systems, after physical weathering $\left(100 \mathrm{x} \mathrm{g}, 25^{\circ} \mathrm{C}\right.$ for $48 \mathrm{~h}$ ); crude oil was supplemented with $0.1 \%(\mathrm{v} / \mathrm{v})$ of squalene $\left(\mathrm{C}_{30} \mathrm{H}_{50}\right.$, Sigma-Aldrich, Milan) as internal spike for measure of bio-degradation rate.

\section{Sampling strategy and parameters assayed}

At the beginning $\left(\mathrm{T}_{0}\right)$ and at the end $\left(\mathrm{T}_{15}\right)$ of the experimental period, sub-samples of each bacterial cultures were taken aseptically. Measures of direct bacterial count (DAPI), microbial viability (Live/Dead staining) and microbial activity (Card-FISH) were carried out. Measure of oil degradation was carried out as well. All experiments were carried out twice and all parameters detected were measured three times.

\section{Total bacterial abundance (DAPI count)}

After a short-time (30") ultrasonic treatment (Ultrasonic Bath Branson 1200, Branson, USA), the total bacterial cell counts were performed by DAPI (4',6-diamidino2- phenylindole $2 \mathrm{HCl}$, Sigma-Aldrich S.r.L., Milan, Italy) staining on samples fixed by formaldehyde ( $2 \%$ final concentration), according to Porter and Feig (1980) and Cappello et al., 2012. Slides were examined by epifluorescence by using Axioplan 2 Imaging (Zeiss; Carl Zeiss Inc., Thornwood, N.Y.) microscope. Results were expressed as number of cells $\mathrm{mL}^{-1}$.

\section{Determination of living and dead bacteria}

Living and dead bacteria (L/D) were enumerated after staining with the Live/Dead (BacLight bacterial Viability Kit (Invitrogen Corp; Molecular Probes, Inc Eugene, OR, USA). The above mentioned method allowed discrimination, within the total bacterial community, of the living cells, labelled by SYTO 9 and green-fluorescing, from the dead ones, labelled by propidium iodide and red-fluorescing (Zampino et al., 2004). Cell counts, performed by an Axioplan epifluorescence microscope (Zeiss; Carl Zeiss Inc., Thornwood, N.Y., USA) equipped with a $100 \mathrm{~W} \mathrm{Hg}$ lamp using fluorescein (BP 450-490; FT 510; LP 520) and rhodamine (BP 546/12; FT 580; LP 590) filter sets (for live and dead cells, respectively). Data obtained were reported as the mean value of (living and dead) cells $\mathrm{mL}^{-1}$.

\section{Card-FISH}

Card-FISH analysis was carried out according to protocol developed by Pernthaler et al. (2002). Aliquot of $1 \mathrm{~mL}$ of bacterial culture was filtered on $0.22 \mu \mathrm{m}$ polycarbonate membranes (diameter $25 \mathrm{~mm}$ ) by using a vacuum filtration device (Millipore, Milan, Italy). Filters for Card-FISH counts were embedded in low-gelling point (0.1\% agarose, Sigma-Aldrich, Milan), dried at $37{ }^{\circ} \mathrm{C}$ for 20 min, and dehydrated with $95 \%$ ethanol. The bacteria on the polycarbonate membrane were then permeabilized by lysozyme (solution (EDTA 0.05 M; $1 \mathrm{M}$ Tris-HCl, pH 8.0; MilliQ water and $10 \mathrm{mg} \mathrm{mL}^{-1}$ lysozyme) for $60 \mathrm{~min}$ at $37^{\circ} \mathrm{C}$ and in some cases a treatment with achromopeptidase (60 U, 0.01 M NaCl, 0.01 M Tris- $\mathrm{HCl}[\mathrm{pH} 8.0]$ ) was performed. Filters were incubated at $37^{\circ} \mathrm{C}$ for $30 \mathrm{~min}$ and hybridized with oligonucleotide probes modified at the 5 ' end with horseradish peroxidase (HRP). Probes used in this work are listed in the Table 1.

After the hybridization and amplification steps, slides were examined by an Axioplan epifluorescence microscope (Zeiss; Carl Zeiss Inc., Thornwood, N.Y., USA) equipped with an appropriate filter sets for Card-FISH. Before counting, the slides were stored at $-20{ }^{\circ} \mathrm{C}$ for several days without any loss of fluorescence intensity. Cell counts were reported as the mean value of cells $\mathrm{mL}^{-1}$.

\section{Hydrocarbon analysis}

The composition of the Total Extracted and Resolved Hydrocarbons and their derivates (TERHCs) were analysed by high-resolution GC-FID (DANI Master GC Fast Gas Chromatograph System, DANI Instruments Sp.A., Milan). After acidification, TERHCs from samples were extracted at room temperature on a shaking table by using dichloromethane $\left(\mathrm{CH}_{2} \mathrm{Cl}_{2}\right.$, Sigma-Aldrich, Milan; 10\% v/v). This procedure was repeated three times, and the $\mathrm{CH}_{2} \mathrm{Cl}_{2}$ phase was combined and treated with sodium sulfate anhydrous $\left(\mathrm{Na}_{2} \mathrm{SO}_{4}\right.$, Sigma-Aldrich, Milan) in order to remove any residual water (Ehrhardt et al., 1991; Wang et al., 1998; Dutta

Table 1 - Oligonucleotide probes used in Card-FISH for this study.

\begin{tabular}{llcc}
\hline Probe & Sequence (5' to 3') of probe & Specificity & Source \\
\hline NON-Eub338 & ACA TCC TAC GGG AGG C & Negative Control & (Wallner et al. , 1993) \\
Eub338 & GCT GCC TCC CGT AGG AGT & Domain Bacteria & (Amann et al. , 1990) \\
Alk & CG ACG CGA GCT CAT CCA TCA & Alcanivorax genus & (Karner and Fuhrman ,1997) \\
\hline
\end{tabular}


and Harayama 2001; Denaro et al., 2005). Extracts were concentrated by rotary evaporation (Rotavapor model R110; Büchi Labortechnik AG, Switzerland) at room temperature $\left(<30^{\circ} \mathrm{C}\right)$, followed by evaporation under a stream of nitrogen and taken up into a solution containing heptamethyl-nonane as an internal standard $\left(79 \mu \mathrm{g} \mathrm{mL}^{-1}\right)$. Indices selected for this study were: $n-\mathrm{C} 17 /$ Pristane $(n \mathrm{C} 17 / \mathrm{Pr})$, $n$-C18/Phytane $(n \mathrm{C} 18 / \mathrm{Ph})$ in order to evaluate the relative biodegradation of $n$-alkanes.

\section{Biodegradation efficiency (BE) of TERCHs}

The degradation of TERCHs was expressed as the percentage of TERCHs degraded in relation to the amount of the remaining fractions in the appropriate abiotic control samples. The biodegradation efficiency (BE), based on the decrease in the total concentration of hydrocarbons, was calculated by using the expression described by Michaud et al., 2004:

$$
100-(\mathrm{As} * 100 / \mathrm{Aac})
$$

where As = total area of peaks in each sample, Aac $=$ total area of peaks in the appropriate abiotic control, $\mathrm{BE}(\%)=$ Biodegradation efficiency.

\section{Statistical analysis and nMDS}

The experimental data are presented in terms of arithmetic averages of at least three replicates and the standard deviations are indicated by error bars. The non-metric multi-dimensional (nMDS) scaling plot were done using
PAST (PAlaeontological STatistics Software ver. 1.88; Hammer et al., 2001).

\section{Results}

\section{Total bacterial abundance (DAPI count)}

After 15 days of cultivation, the bacterial abundance was measured by direct DAPI count; and data obtained were compared with the quantity of cells present at the beginning of the experimental period $\left(\mathrm{T}_{0}\right)$. The data obtained showed, how in seawater added with inorganic nutrients it was possible to observe a general increase of microbial abundance (systems "A", "A + P", "A + R," "P + R", and “ $\mathrm{A}+\mathrm{P}+\mathrm{R}$ ”) with mean values of $10^{8}$ cell $\mathrm{mL}^{-1}$. In cultures performed using seawater (without inorganic nutrients), bacterial abundance present, at the end of experimental period, mean values of $10^{6}$ cell $\mathrm{mL}^{-1}$ (systems "P", "R", "A + P" and "A + P + R"); in microcosms indicated as "A", "A + R", and "P + R") values of $\sim 10^{5}$ cell $\mathrm{mL}^{-1}$ were observed (Fig. 3).

\section{Determination of living and dead bacteria}

Data of living and dead bacteria (L/D) enumerated using the Live/Dead staining are showed in Figure 4.

The results obtained after 15 days of cultivation shown as the vital bacterial fraction, present in microcosm performed in seawater with addition of inorganic nutrients, was greater than that observed in the microcosms performed in sea water. In particular in microcosms indicated

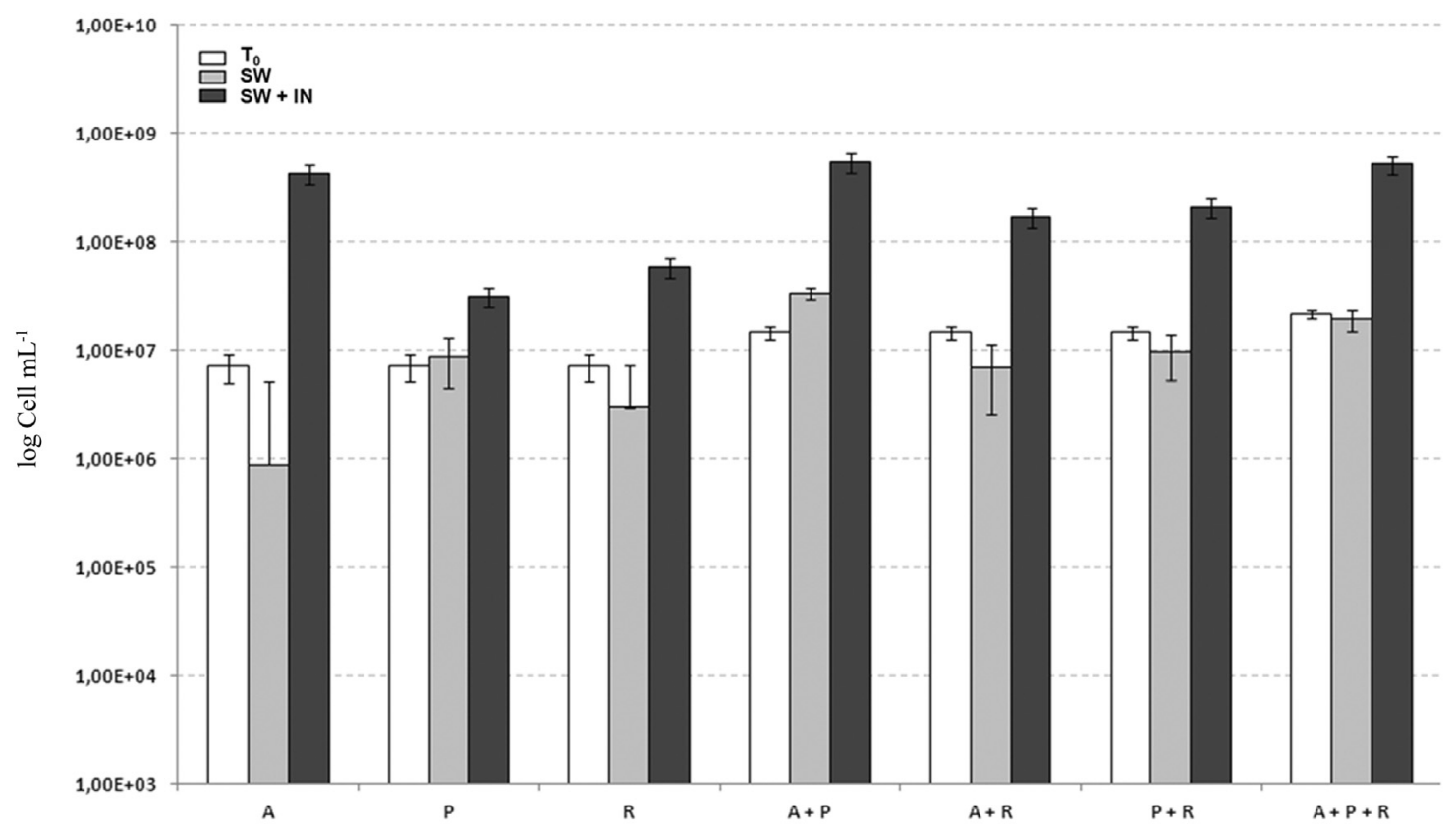

Figure 3 - Measure of bacterial abundance by direct DAPI count in cultures obtained in seawater without addition of inorganic nutrients (grey bars) and with addition of inorganic nutrients (dark grey bars). A, iso-SS-01 (Alcanivorax borkumensis SK2 ${ }^{\mathrm{T}}$ ); $\mathrm{P}$, iso-SS-02 (Pseudomonas stuzteri SMD) and R, iso-SS-03 (Rhodococcus erythropolis HS4). 


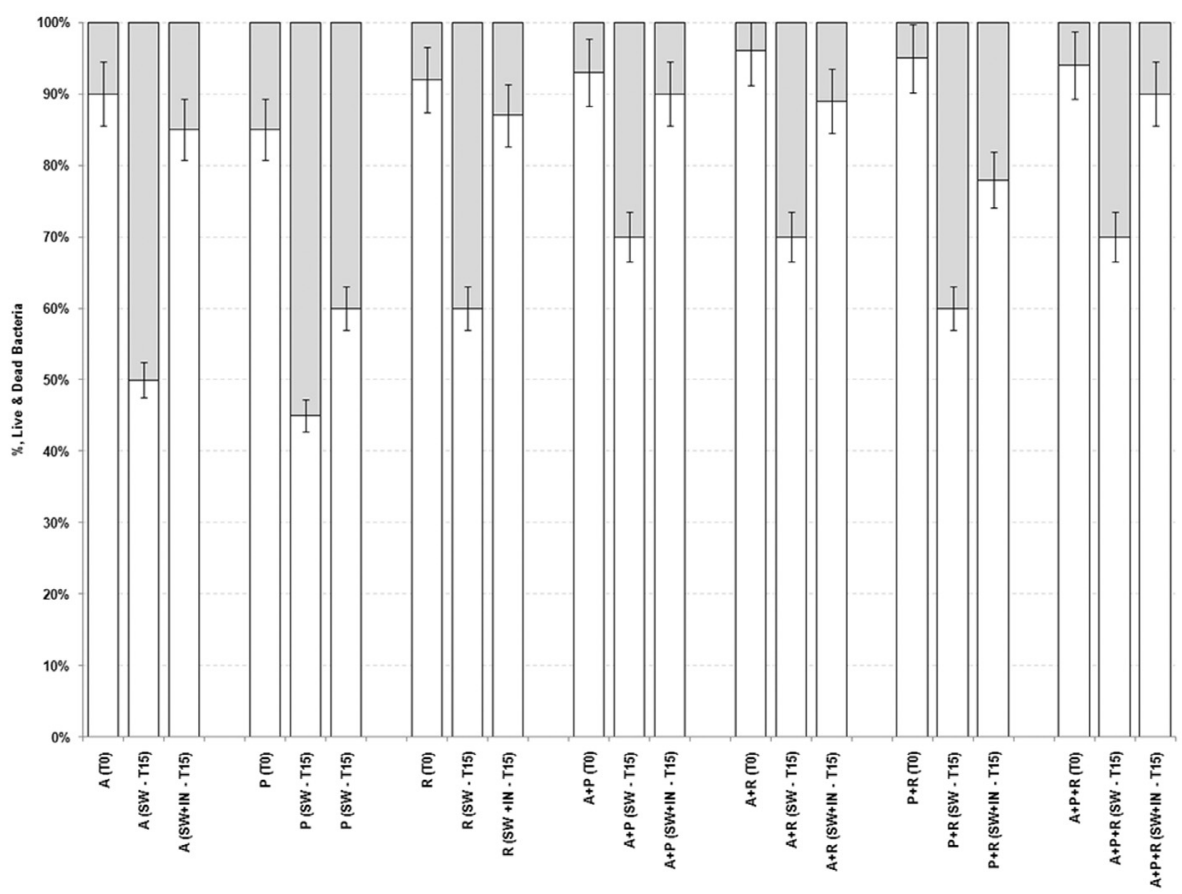

Figure 4 - Results of living and dead bacteria (L/D) in cultures obtained in seawater with and without addition of inorganic nutrients. A, iso-SS-01 (Alcanivorax borkumensis SK2 ${ }^{\mathrm{T}}$ ); P, iso-SS-02 (Pseudomonas stuzteri SMD); R, iso-SS-03 (Rhodococcus erythropolis HS4); withe bars, live cells; grey bars, dead cells.

as SW the percentage of dead cells was about four or six times greater than the initial time.

\section{Card-FISH}

The qualitative measure of microbial abundance, into the experimental systems named " $\mathrm{A}+\mathrm{P}$ " and " $\mathrm{A}+\mathrm{R}$ ", was carried out by using the card-FISH method. Values of abundance of cells hybridized using probes for Eubacteria (EUB338) resulted to be similar to the values obtained from the measure of total bacterial abundance (DAPI count) in the same conditions.

Data obtained put in evidence as almost total cells of experimentations carried out with seawater without inorganic nutrients were hybridized by probes for Eubacteria. The same result was not obtained during experimentations carried out with seawater added with inorganic nutrients (in such a case a number of cells of a lower logarithmic order has been obtained). The data obtained showed as the quantity of cells of Alcanivorax borkumensis (in "A + P", $\mathrm{SW}+\mathrm{IN}$; “A + R", SW and "A+ R", SW + IN systems) present values lower (of a logarithmic order) those obtained in total cells (Fig. 5).

\section{Rate of degradation of n-alkanes}

The percentage degradation of n-alkanes $\left(\mathrm{C}_{12}-\mathrm{C}_{30}\right)$ present in the crude oil was calculated by comparison of the gas chromatograms of the non degraded (abiotic) control and the degraded sample for each experimental conditions (Table 2 and Fig. 6).

During experimentations performed with natural seawater the condition identified as " $\mathrm{A}+\mathrm{P}+\mathrm{R}$ " showed a better rate degradation $(\sim 90 \%)$; also in system " $A+R$ " in other conditions is possible to observe a degradation of almost all n-alkanes (rate of degradation $>$ of $60 \%$ ).

The data obtained show that, during growth in natural seawater added with inorganic nutrients, conditions " $\mathrm{A}$ ", "R", "A+P", "A+R" and "A+P+R" n-alkanes present in the crude oil were totally degraded; in contrast, conditions " $P$ " and " $\mathrm{P}+\mathrm{R}$ " present a low rate of degradation of n-alkanes.

For all strains, n-alkanes with a medium length $\left(\mathrm{C}_{12}-\right.$ $\mathrm{C}_{18}$ ) were degraded to a greater extent (rate of degradation $>$ of $\sim 70 \%$ ) than and long chains $\left(\mathrm{C}_{19}-\mathrm{C}_{30}\right)$ because longchain n-alkanes are solid and their low solubility inhibits degradation by bacteria (Figs. 7 and 8).

\section{Biodegradation efficiency (BE) of TERCHs}

After 15 days of experimentation, measure of degradation of the TERHCs revealed as major rates of oil degradation are, in general, observed in systems carried out in natural seawater with inorganic nutrients (Table 3). In SW experiment the maximum rate of total oil degradation is observed in "A+P+R" $(\sim 97 \%)$ and "A+R" system $(\sim 83 \%)$. Other conditions present similar values. In system $\mathrm{SW}+\mathrm{IN}$ the experimentations identified " $\mathrm{A}$ ", " $\mathrm{A}+\mathrm{P}$ ", " $\mathrm{A}+\mathrm{R}$ " and " $\mathrm{A}+\mathrm{P}+\mathrm{R}$ " the degradation of oil is total; values of $\sim 90 \%$, 


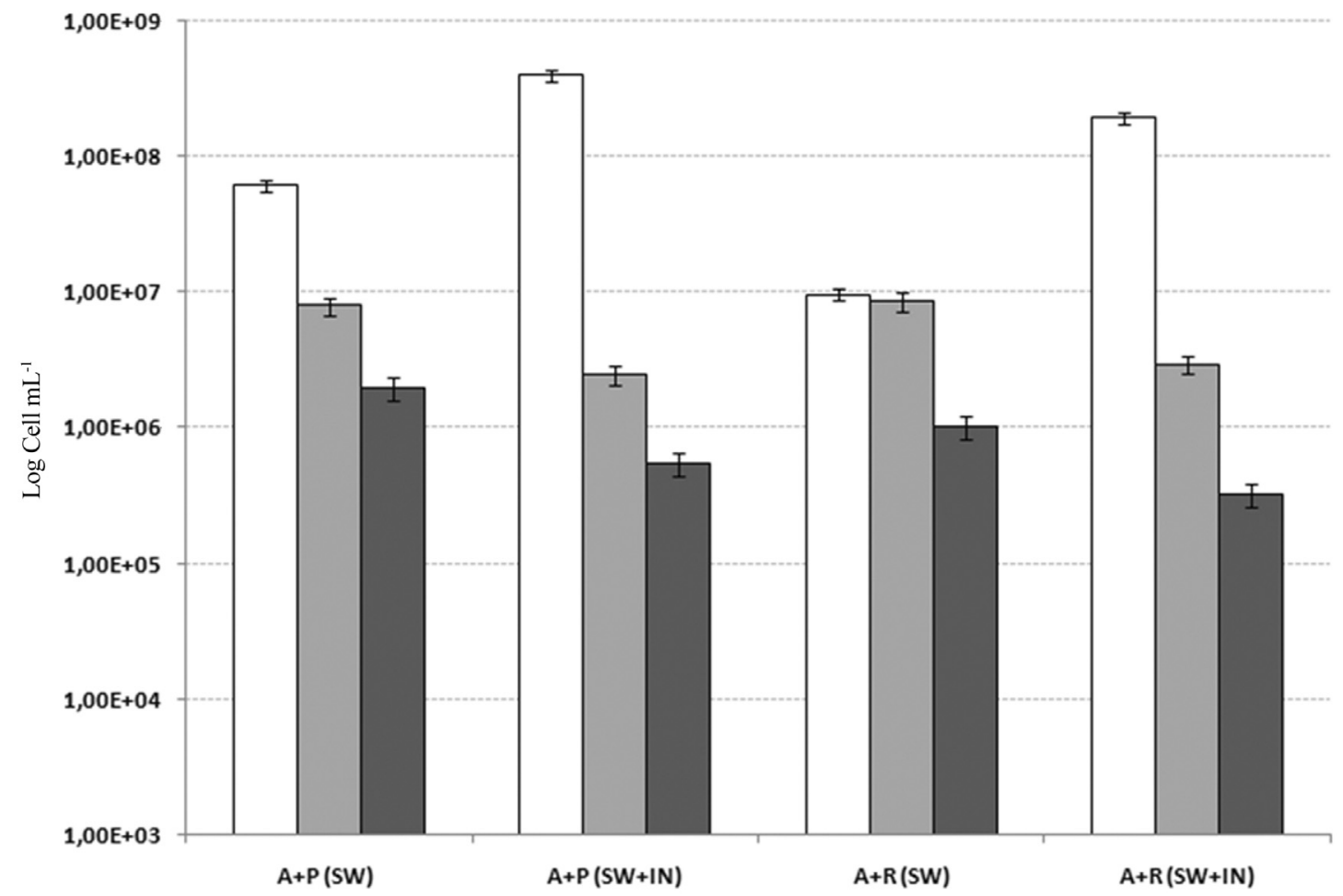

Figure 5 - Bacterial abundance detected by card-FISH in bacterial consortia ("A+P" e "A + R") during growth in natural seawater in absence (SW) and presence $(\mathrm{SW}+\mathrm{IN})$ of inorganic nutrients. Results obtained with hybridization with probe for Eubacteria and Alcanivorax sp. are indicated, respectively, with grey and dark grey bars. Bacterial total count (DAPI) was indicated in white bars.

$\sim 64 \%$ and $\sim 30 \%$ of total oil degradation were observed for "P", "R" and "P+R" experiments (Fig. 6).

\section{Discussion}

The recovery of petroleum contaminated sites could be achieved by either physicochemical or biological methods. Due to negative consequences of the physicochemical approach, more attention is now given to the exploitation of biological alternatives (Okoh, 2006).

Biological treatments are having more importance, mainly because of the low environmental impact, the costs (in general cheaper than other cleanup technologies), the capability to destroy organic contaminants, and the possibility of beneficial use of treated sediments (Rulkens and Bruning, 2005). Different studies have shown better results using bioremediation strategies (Beolchini et al., 2010; Rocchetti et al., 2011, 2012).

In general, bioremediation is often based on in-situ stimulation of the microbial community (biostimulation) or amending the microbial community with an inoculum of hydrocarbon-degrading bacteria (bioaugmentation). In both cases, the successful result of bioremediation depends on appropriate hydrocarbon-degrading consortia and environmental conditions.

In this study we have analyzed the cooperative action of mixed microbial populations in the biodegradation of crude oil during different culture conditions. All data obtained confirmed the fundamental role of bacteria belonging to Alcanivorax genus in degradation of linear hydrocarbons in oil polluted environments. Indeed, all experimentations carried out in seawater (with or without inorganic nutrients) whit presence of Alcanivorax showed maximum rates of oil degradation.

Capability of Alcanivorax genus to use hydrocarbons as the only sources of energy and organic carbon was widely (Yakimov et al., 1998; Scheiner et al., 2006). Kasai (2002) and Cappello (2012) explain these characteristics in ability of this strain to produce a lipidic bio-surfactant that increases the bioaviable of contaminant and the ability to use this (Yakimov et al., 1998; Scheiner et al., 2006). Alcanivorax borkumensis SK2 surfactant propose as one of the most efficient of bacterial surfactants; the possible presence of this surfactant can justify an increase in the rates of degradation by both the bacteria that possible microbial consortia. This defines an increment of rates of degradation by both the bacteria and possible microbial consortia (Yakimov et al., 1998; Scheiner et al., 2006).

The presence of Alcanivorax in natural environment or enrichment by laboratory is generally combined with the presence of other bacterial strains, such as Pseudomonas sp. and Rhodococcus sp., that participating in biodegradation phenomena. However, Pseudomonas sp. and Rhodococcus sp., can not be classified such as hydro- 
Table 2 - Percentage of $n$-alkane degradation in crude oil by strains in this study after 15 days of incubation at $22 \pm 1{ }^{\circ} \mathrm{C}$ with shaking $(100 \mathrm{~g})$. Table Top, bacterial culture $\mathrm{s}$ in natural sea water; Table Lower, Bacterial cultures performed in natural seawater with inorganic nutrients. A, Alcanivorax borkumensis SK2; P, Pseudomonas stuzteri SMD; R, Rhodococcus erythropolis HS4.

\begin{tabular}{lccccccc}
\hline n-alkanes & \multicolumn{7}{c}{ Natural sea water } \\
\cline { 2 - 7 } & $\mathrm{A}$ & $\mathrm{P}$ & $\mathrm{R}$ & $\mathrm{A}+\mathrm{P}$ & $\mathrm{A}+\mathrm{R}$ & $\mathrm{P}+\mathrm{R}$ & $\mathrm{A}+\mathrm{P}+\mathrm{R}$ \\
\hline $\mathrm{C}_{12}$ & 95 & 80 & 82 & 86 & 100 & 90 & 99 \\
$\mathrm{C}_{13}$ & 69 & 52 & 57 & 68 & 94 & 92 & 96 \\
$\mathrm{C}_{14}$ & 56 & 45 & 48 & 52 & 74 & 94 & 77 \\
$\mathrm{C}_{15}$ & 42 & 42 & 49 & 51 & 82 & 94 & 92 \\
$\mathrm{C}_{16}$ & 46 & 46 & 52 & 57 & 81 & 93 & 92 \\
$\mathrm{C}_{17}$ & 51 & 48 & 53 & 57 & 79 & 91 & 92 \\
$\mathrm{C}_{18}$ & 52 & 49 & 56 & 57 & 81 & 89 & 93 \\
$\mathrm{C}_{19}$ & 63 & 63 & 68 & 65 & 82 & 88 & 94 \\
$\mathrm{C}_{20}$ & 60 & 59 & 64 & 62 & 78 & 86 & 93 \\
$\mathrm{C}_{21}$ & 66 & 67 & 70 & 68 & 79 & 82 & 93 \\
$\mathrm{C}_{22}$ & 68 & 69 & 72 & 67 & 80 & 79 & 94 \\
$\mathrm{C}_{23}$ & 77 & 77 & 80 & 74 & 84 & 79 & 95 \\
$\mathrm{C}_{24}$ & 66 & 68 & 71 & 62 & 78 & 69 & 94 \\
$\mathrm{C}_{25}$ & 74 & 75 & 78 & 70 & 82 & 66 & 95 \\
$\mathrm{C}_{26}$ & 75 & 77 & 79 & 71 & 84 & 66 & 95 \\
$\mathrm{C}_{27}$ & 75 & 76 & 78 & 70 & 83 & 53 & 95 \\
$\mathrm{C}_{28}$ & 75 & 76 & 79 & 70 & 84 & 47 & 95 \\
$\mathrm{C}_{29}$ & 73 & 73 & 77 & 67 & 83 & 37 & 95 \\
$\mathrm{C}_{30}$ & 76 & 77 & 81 & 72 & 87 & 31 & 96 \\
\hline & & & & & & 95 &
\end{tabular}

\begin{tabular}{lccccccc} 
n-alkanes & \multicolumn{7}{c}{ Natural sea water + inorganic nutrient } \\
\cline { 2 - 7 } & $\mathrm{A}$ & $\mathrm{P}$ & $\mathrm{R}$ & $\mathrm{A}+\mathrm{P}$ & $\mathrm{A}+\mathrm{R}$ & $\mathrm{P}+\mathrm{R}$ & $\mathrm{A}+\mathrm{P}+\mathrm{R}$ \\
\hline $\mathrm{C}_{12}$ & 100 & 87 & 100 & 100 & 100 & 100 & 100 \\
$\mathrm{C}_{13}$ & 100 & 88 & 97 & 100 & 100 & 100 & 100 \\
$\mathrm{C}_{14}$ & 100 & 89 & 95 & 100 & 100 & 100 & 100 \\
$\mathrm{C}_{15}$ & 100 & 82 & 91 & 100 & 100 & 100 & 100 \\
$\mathrm{C}_{16}$ & 100 & 84 & 95 & 100 & 100 & 90 & 100 \\
$\mathrm{C}_{17}$ & 100 & 85 & 95 & 100 & 100 & 81 & 100 \\
$\mathrm{C}_{18}$ & 100 & 83 & 94 & 100 & 100 & 94 & 100 \\
$\mathrm{C}_{19}$ & 100 & 83 & 90 & 100 & 100 & 80 & 100 \\
$\mathrm{C}_{20}$ & 100 & 82 & 92 & 100 & 100 & 80 & 100 \\
$\mathrm{C}_{21}$ & 100 & 81 & 90 & 100 & 100 & 77 & 100 \\
$\mathrm{C}_{22}$ & 100 & 81 & 92 & 100 & 100 & 72 & 100 \\
$\mathrm{C}_{23}$ & 100 & 83 & 90 & 100 & 100 & 71 & 100 \\
$\mathrm{C}_{24}$ & 100 & 76 & 87 & 100 & 100 & 63 & 100 \\
$\mathrm{C}_{25}$ & 100 & 77 & 90 & 100 & 100 & 68 & 100 \\
$\mathrm{C}_{26}$ & 100 & 77 & 86 & 100 & 100 & 70 & 100 \\
$\mathrm{C}_{27}$ & 100 & 75 & 87 & 100 & 100 & 71 & 100 \\
$\mathrm{C}_{28}$ & 100 & 75 & 86 & 100 & 100 & 69 & 100 \\
$\mathrm{C}_{29}$ & 100 & 75 & 81 & 100 & 100 & 71 & 100 \\
$\mathrm{C}_{30}$ & 100 & 77 & 87 & 100 & 100 & 62 & 100 \\
\hline & & & & & & &
\end{tabular}

Table 3 - Biodegradation efficiency (BE) of TERCHs. The experimental data are presented in terms of arithmetic averages.

\begin{tabular}{lcc}
\hline Code & Natural sea water & Natural sea water+IN \\
\hline A & 64 & 100 \\
P & 48 & 64 \\
R & 64 & 90 \\
$\mathrm{~A}+\mathrm{R}$ & 66 & 100 \\
$\mathrm{~A}+\mathrm{P}$ & 83 & 100 \\
$\mathrm{P}+\mathrm{R}$ & 73 & 60 \\
$\mathrm{~A}+\mathrm{P}+\mathrm{R}$ & 93 & 100 \\
\hline
\end{tabular}

carbonoclastic bacteria (Marine Obligate Hydrocarbonoclastic Bacteria, OMHCB; Yakimov et al., 2007), but these are heterotrophic bacteria that participate in the biodegradation processes via "syntrophy metabolic" "in which the degradation of pollutant compounds takes place via a metabolic chain, in which the product of the catabolism of a bacterial species is identified as a source of carbon for metabolic another.

Analysis of microbial abundance in cultures in study showed, however, a divergence of the correlation between microbiological data and those of biodegradation. In experimentation carried out with Alcanivorax and Pseudomonas (system "A", "P" and "A+P") was possible to observe after 15 days to incubation in seawater with and without inorganic nutrients an increase of microbial biomass.

Data obtained during cultivation of Rhodococcus erythropolis (as single strain and/or as consortium) did not show, apparently, increment of microbial abundance. This condition may be due to an underestimation of the direct count (DAPI count) in cultures as result from an inefficiency of methodology used by us for the separation of microbial cells from oil remain (dislodging).

Rhodococcus erythropolis HS4, in presence of linear hydrocarbons, is usually produced trehalose lipids (Rapp, 1979); these molecules are composed of a disaccharide in combination with a long chain of fatty acids. The presence of these molecules define a general reduction of superficial (surface) tension such as increase of cellular hydrophobicity and consequently increase of bacterial tackiness.

Another important aspect was obtained to qualitative measures of microbial abundance. Card-FISH analysis carried out to estimate quantitative abundance of bacteria belonging to Alcanivorax genus in microbial consortia tested in this study. Therefore Card-FISH measures were realized for identified consortia $\mathrm{A}+\mathrm{P}$ and $\mathrm{A}+\mathrm{R}$ realized in seawater with and without inorganic nutrients. Hybridization with EUB-338 probe showed values similar to these obtained by direct DAPI count; for against assays carried out with ALK probe (specific probe to Alcanivorax genus) evidence as only the $15 \%$ of total cells were hybridized. This result can seem discordant with biodegradation results. However, it is important remember that the sample to Card-FISH was col- 


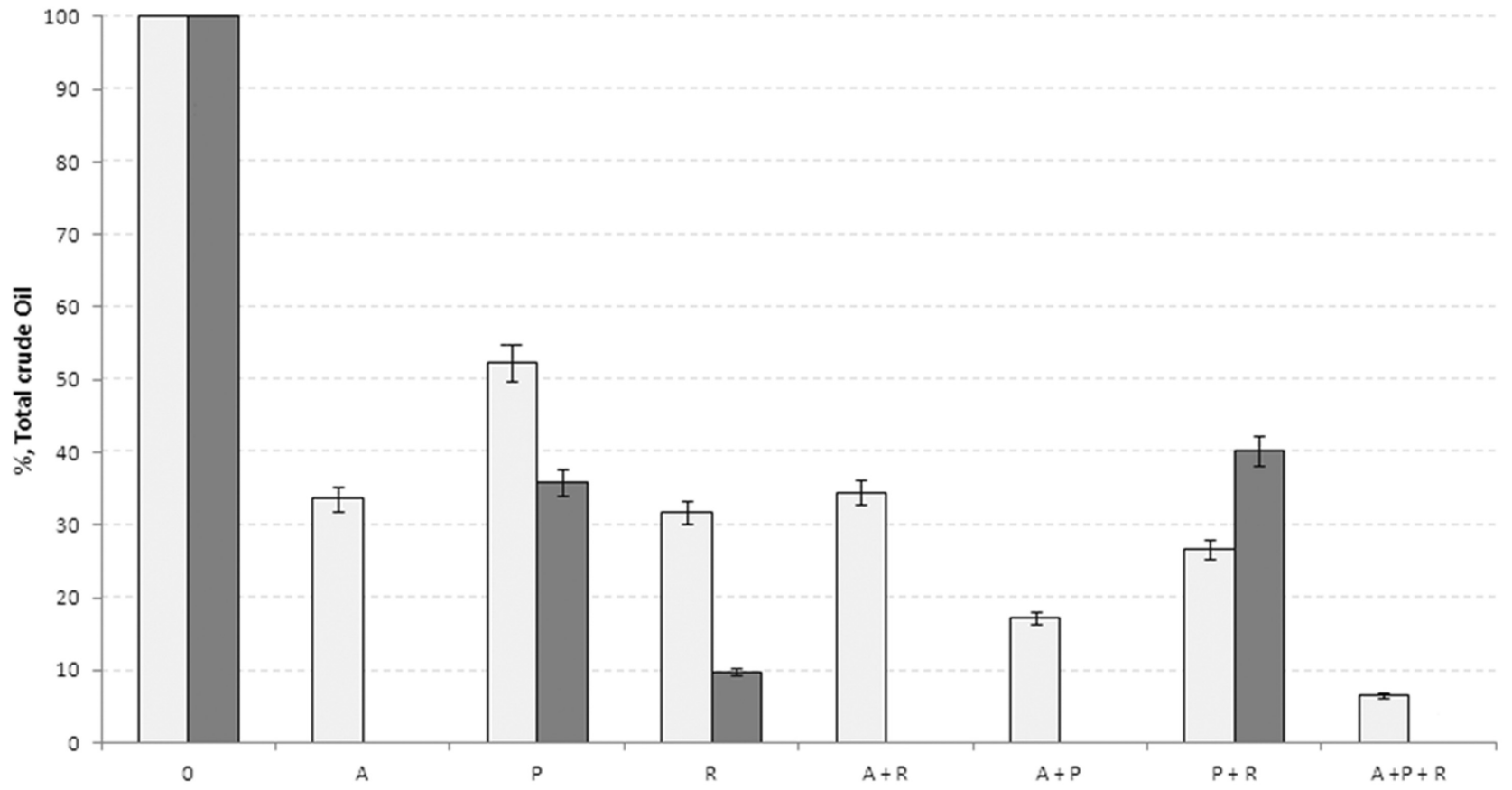

Figure 6 - Relative values of major TERHC fractions of Arabian Light Crude Oil detected in SW and SW+IN cultures after 15 days of incubation; data expressed as the percentages compared to negative abiotic control (0). A, Alcanivorax borkumensis SK2; P, Pseudomonas stuzteri SMD; R, Rhodococcus erythropolis HS4. Experimentations carried out in natural seawater in absence (SW) and presence (SW + IN) of inorganic nutrients were indicated, respectively, with grey and dark grey bars.

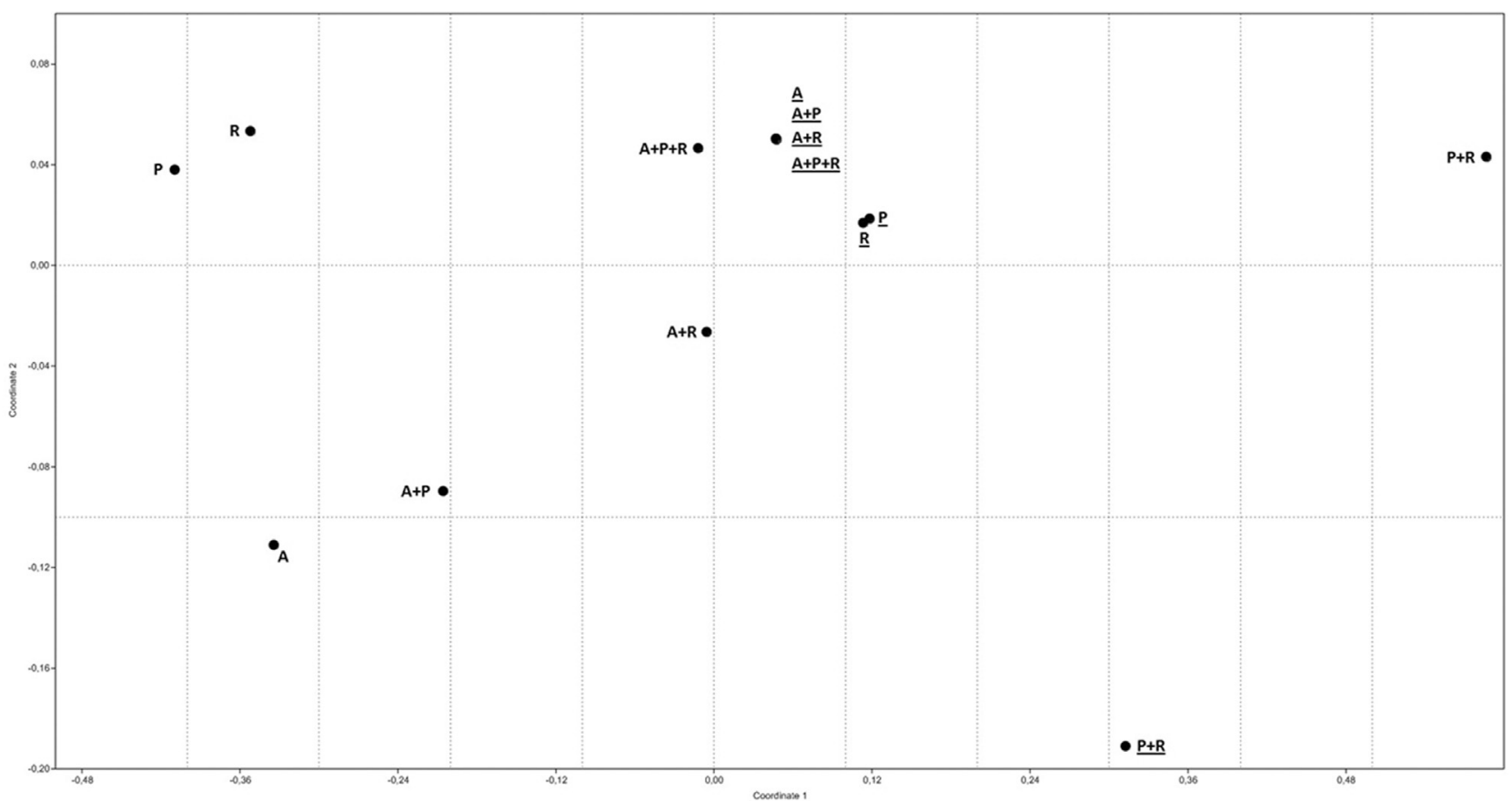

Figure 7 - The non-metric multi-dimensional (nMDS) scaling plot related to the capability biodegradation of n-alkanes of different bacteria and consortia in study. A, Alcanivorax borkumensis SK2; P, Pseudomonas stuzteri SMD; R, Rhodococcus erythropolis HS4. Normal letter indicate the Natural Sea Water experimentation (SW), underlined letters indicate the Natural Sea Water + Inorganic Nutrients (SW + IN) experimentation. 


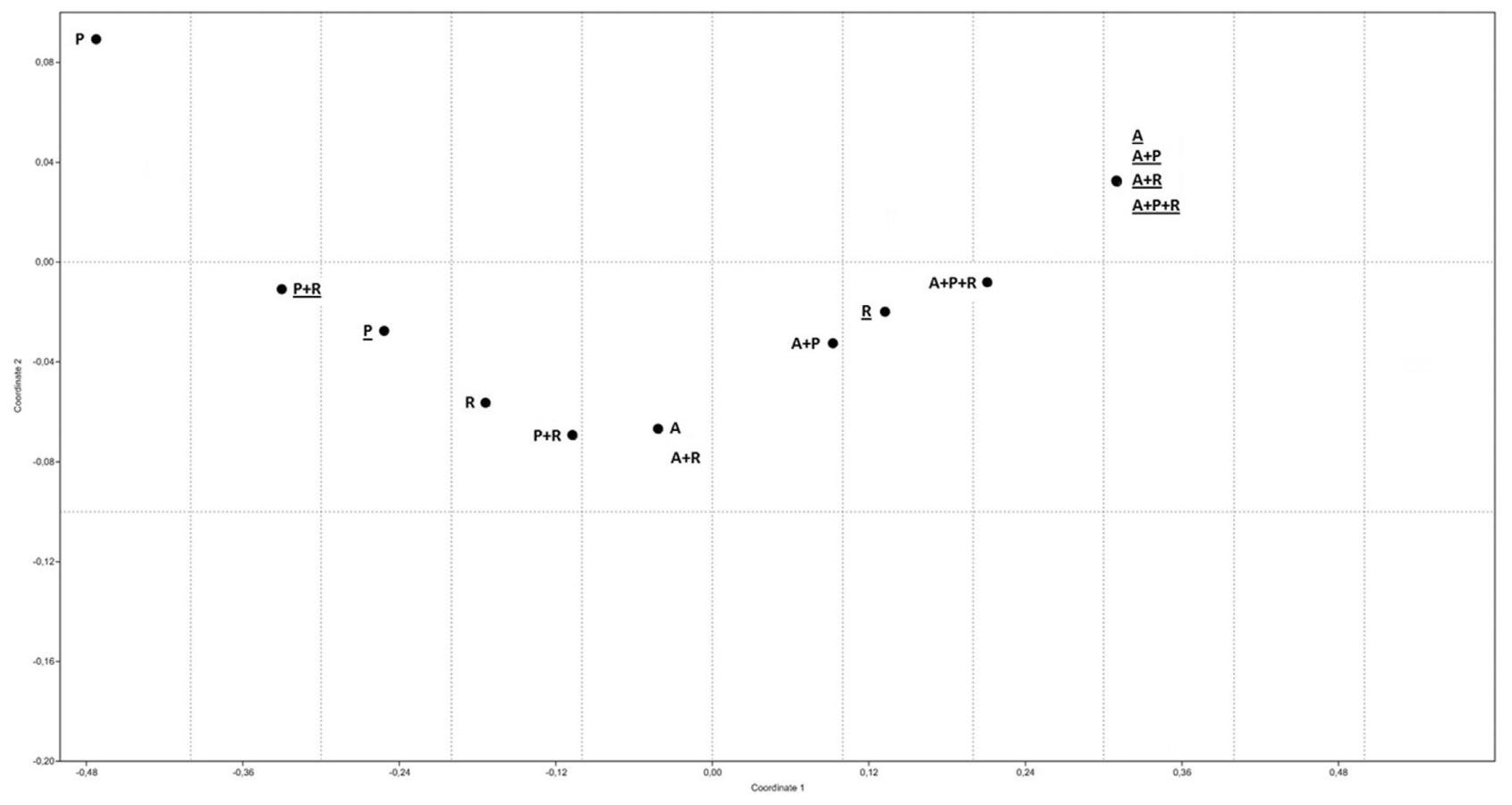

Figure 8 - The non-metric multi-dimensional (nMDS) scaling plot related to the biodegradation efficiency (BE) of TERCHs of different bacteria and consortia in study. A, Alcanivorax borkumensis SK2; P, Pseudomonas stuzteri SMD; R, Rhodococcus erythropolis HS4. Normal letter indicate the Natural Sea Water experimentation (SW), underlined letters indicate the Natural Sea Water + Inorganic Nutrients (SW + IN) experimentation.

lected after 15 days of incubation, therefore is possible that the cells were collected in advance stationary phase and/or not more active. Supposing that the oil degradation process began early of the end of experiment, Alcanivorax sp. , dominant at the first experimental phase, tended to disappear or decrease once hydrocarbons have been degraded, while Pseudomonas sp. and Rhodococcus sp. cells could become dominant using metabolic compounds or cellular lysates like nutritional source.

\section{Acknowledgments}

This work was supported by grants of National Counsel of Research (CNR) of Italy and by: i) EC Project "Unraveling and exploiting Mediterranean Sea microbial diversity and ecology for XEnobiotics' and pollutants' clean up" (ULIXES-FP7-KBBE-2010-3.5-03); ii) Italian Project PRIN2010-2011 "La "System Biology" nello studio degli effetti di xenobiotici in organismi marini per la valutazione dello stato di salute dell'ambiente: applicazioni biotecnologiche per potenziali strategie di ripristino"; iii) National Operative Project PON R\&C 2007-2013 "Sviluppo di Tecnologie Innovative per il trattamento dei rifiuti liquidi della navigazione finalizzate alla Tutela dell'Ambiente Marino" (STI-TAM); iv) National Operative Project PON R\&C 2007-2013 “Sviluppo di tecnologie innovative per la Sostenibilità Energetica ed Ambientale di cantieri nautici ed aree Portuali” (SEA-PORT).

\section{References}

Alkatib MA, Alam MDZ, Muyibi SA et al. (2011) An isolated bacterial consortium for crude oil biodegradation. Afr J Biotechnol 10:18763-18767.

Atlas RM (1981) Microbial degradation of petroleum hydrocarbons: an environmental perspective. Microbiol Rev 45:180-209.

Beolchini F, Rocchetti L, Regoli L et al. (2010) Bioremediation of marine sediments contaminated by hydrocarbons: experimental analysis and kinetic modelling. J Hazard Mater 182:403-407.

Cappello S, Caruso G, Zampino D et al. (2007) Microbial community dynamics during assays of harbour oil spill bioremediation: a microscale simulation study. J Appl Microbiol 102:184-194.

Cappello S, Denaro R, Genovese M et al. (2007) Predominant growth of Alcanivorax during experiments on "oil spill bioremediation" in mesocosms. Microbiol Res 162:185-190.

Cappello S, Genovese M, Della Torre C et al. Effect of bioemulsificant exopolysaccharide $\left(\mathrm{EPS}_{2003}\right)$ on microbial community dynamics during assays of oil spill bioremediation: A microcosm study. Mar Pollut Bull 64:2820-2282.

Cappello S, Guglielmino SPP (2006) Effects of growth temperature on polystyrene adhesion of Pseudomonas aeruginosa ATCC27853. Braz J Microbiol 37:205-207.

Cappello S, Yakimov MM (2010) Alcanivorax. In handbook of hydrocarbon and lipid microbiology. In: Timmis KN, McGenity TJ, van der Meer et al. (eds). Springer, Berlin, pp. $1738-1745$. 
Cefalì E, Patanè S, Arena A et al. (2002) Morphologic variations in bacteria under stress conditions: Near-field optical studies. Scanning 24:274-283.

Das N, Chandran P (2011) Microbial degradation of petroleum hydrocarbon contaminants: an overview. Biotechnol Res Int doi: $10.4061 / 2011 / 941810$

Della Torre C, Tornambè A, Cappello S et al. (2012) Modulation of CYP1A and genotoxic effects in European seabass Dicentrarchus labrax exposed to weathered oil: A mesocosm study. Mar Environ Res 76:48-55.

Denaro R, D'Auria G, Di Marco G et al. (2005) Assessing terminal restriction fragment length polymorphism suitability for the description of bacterial community structure and dynamics in hydrocarbon-polluted marine environments. Environ Microbiol 7:78-87.

Dutta TK, Harayama S (2001) Analysis of long-side chain alkylaromatics in crude oil for evaluation of their fate in the environment. Environ Sci Technol 35:102-107.

Dykesterhouse S, Gray J, Herwig RP et al. (1995) Cycloclasticus pugetii, gen. et sp. nov., an aromatic hydrocarbon-degrading bacterium from marine environments. Int J Syst Evol Microbiol 45:116-123

Ehrhardt M, Klungsøyr J, Law RJ (1991) Hydrocarbons: review of methods for analysis in sea water, biota, and sediments. ICES Techniques in Marine Environmental Sciences, pp 44.

Hammer Ø, Harper DAT, Ryan PD (2001) PAST: Paleontological statistics software package for education and data analysis. Palaeontol Electronica 4:9-14.

Hassanshahian M, Emtiazi G, Cappello S (2012) Isolation and characterization of crude-oil-degrading bacteria from the Persian Gulf and the Caspian Sea. Mar Pollut Bull 64:7-12.

Hassanshahian M, Emtiazi G, Kermanshahi RK et al. (2010) Comparison of oil degrading microbial communities in sediments from Persian Gulf and Caspian Sea. Soil Sediment Contam 19:277-291.

Kasai Y, Kishira H, Harayama S (2002) Bacteria belonging to the genus Cycloclasticus play a primary role in the degradation of aromatic hydrocarbons released in a marine environment. Appl Environ Microbiol 68:5625-5633.

Kasai Y, Kishira H, Sasaki T et al. (2002) Predominant growth of Alcanivorax strains in oil-contaminated and nutrientsupplemented seawater. Environ Microbiol 4:141-147.

Lane DJ (1991) 16/23S rRNA sequencing. In nucleic acid techniques in bacterial systematic. Stackebrandt E, Goodfellow M (ed.) Wiley, New York pp. 115-175.

Michaud L, Lo Giudice A, Saitta M et al. (2004) The biodegradation efficiency on diesel oil by two psychrotrophic Antarctic marine bacteria during a two-month-long experiment. Mar Pollut Bull 49:405-409.

Nikolopoulou M, Kalogerakis N (2010) Biostimulation strategies for enhanced bioremediation of marine oil spills including chronic pollution. In: Timmis KN (ed) Handbook of hydrocarbon and lipid microbiology. Springer-Verlag, Berlin, pp 2521-2529.

Okoh AI (2006) Biodegradation alternative in the cleanup of petroleum hydrocarbon pollutants. Biotechnology and Molecular Biology Review 1:38-50.

Pernthaler A, Pernthaler J, Amann R (2002) Fluorescence in situ hybridization and catalyzed reporter deposition for the identification of marine bacteria. Appl Environ Microbiol 68:3094-3101.
Rocchetti L, Beolchini F, Ciani M et al. (2011). Improvement of bioremediation performance for the degradation of petroleum hydrocarbons in contaminated sediments. Appl Environ Soil doi:10.1155/2011/319657.

Rocchetti L, Beolchini F, Hallberg KB et al. (2012) Effects of prokaryotic diversity changes on hydrocarbon degradation rates and metal partitioning during bioremediation of contaminated anoxic marine sediments. Mar Pollut Bull 64:1688-1698.

Röling WFM, Milner MG, Jones DM et al. (2002). Robust hydrocarbon degradation and dynamics of bacterial communities during nutrient-enhanced oil spill bioremediation. Appl Environ Microbiol 68:5537-5548.

Röling WFM, Milner MG, Martin Jones D et al. (2004) Bacterial community dynamics and hydrocarbon degradation during a field-scale evaluation of bioremediation on a mudflat beach contaminated with buried oil. Appl Environ Microbiol 70:2603-2613.

Rulkens WH, Bruning H (2005). Cleanup technologies for dredged fine sediments: review and future challenges. Olfenbuttel RF, Withe PJ (eds) Finding Achievable Risk Reduction Solutions Remediation of Contaminated Sediments. Battelle Press, Columbus, p. C6-01.

Schneiker S, Martins dos Santos VA, Bartels D et al. (2006) Genome sequence of the ubiquitous hydrocarbon-degrading marine bacterium Alcanivorax borkumensis. Nat Biotechnol 24:997-1004

Wallner G, Amann R, Beisker W (1993) Optimizing fluorescent in situ hybridization with rRNA-targeted oligonucleotide probes for flow cytometric identification of microorganisms. Cytometry 14:136-143.

Wang Z, Fingas M, Blenkinsopp S et al. (1998) Comparison of oil composition changes due to biodegradation and physical weathering in different oils. J Chromatogr A 809:89-107.

Yakimov MM, Cappello S, Crisafi E et al. (2006) Phylogenetic survey of metabolically active microbial communities associated with the deep-sea coral Lophelia pertusa from the Apulian Plateau, Central Mediterran Sea. Deep-Sea Res 53:62-75.

Yakimov MM, Denaro R, Genovese M et al. (2005) Natural microbial diversity in superficial sediments of Milazzo Harbour (Sicily) and community successions during microcosm enrichment with various hydrocarbons. Environ Microbiol 7:1426-1441.

Yakimov MM, Golyshin PN, Lang S et al. (1998) Alcanivorax borkumensis gen. nov., sp. nov., a new, hydrocarbon-degrading and surfactant-producing marine bacterium. Int J Syst Bacteriol 48:339-348.

Yakimov MM, Timmis KN, Golyshin PN (2007) Obligate oildegrading marine bacteria. Curr Opin Biotechnol 18:257266.

Zampino D, Zaccone R, La Ferla R (2004) Determination of living and active bacterioplankton: a comparison of methods. Chemistry and Ecology 20:411-422.

Zulfiqar AM, Safia A (2012). Degradation of petroleum hydrocarbons by oil field isolated bacterial consortium. Afr J Biotechnol 11:650-658.

\section{Associate Editor: Lara Durães Sette}

All the content of the journal, except where otherwise noted, is licensed under a Creative Commons License CC BY-NC. 